\title{
Lack of effect of ribaminol, TCAP, and magnesium pemoline on recovery from neocerebellar damage*
}

\author{
S. REINIS \\ University of Waterloo, Waterloo, Ont., Canada
}

The neocerebellar cortex lesion in newborn mice caused permanent asymmetry of the position of the hind limbs which was normalized spontaneously in about $27.8 \%$ of control animals. The administration of ribaminol, TCAP, and magnesium pemoline during the first 2 weeks of postnatal life did not improve the rate of recovery from the neocerebellar damage.

Magnesium pemoline has been suggested as a drug to increase the synthesis of RNA in the brain, and to improve learning in laboratory rats (Plotnikoff, 1966). However, there is no clear-cut evidence that any of the substances recommended for the improvement of memory (yeast RNA, Cameron, 1958; ribaminol, Glasky et al, 1968; tricyano-aminopropene, Chamberlain, Rothschild, \& Gerard, 1963) may really penetrate the brain and affect the brain function and metabolism substantially.

These substances may be effective in vitro and in young animals where the blood-brain barrier is not sufficiently developed. This is one of the reasons why we decided to test whether or not the substances promoting proteosynthesis might improve recovery of function in the damaged brain. Another reason was that we had found that there were permanent metabolic changes in the damaged brain concerning enzymatic activity, temprature, oxidations, etc. (Reinis \& Suva, 1966; Reinis, 1960,1961). These changes probably depend on proteosynthesis and control of the cell metabolism by nucleic acids, and may therefore be promoted by substances boosting proteosynthesis.

\section{MATERIAL AND METHODS}

The experiments were carried out with black inbred mice, C57BL/6J, whose ancestors were originally purchased from Jackson's Laboratories (Bar Harbor, Maine). The number of newborn mice in each litter was adjusted to six, and at the age of 24-39 h, the left cerebellar cortex was stabbed with a sharp needle introduced through the occiptal plane about 1-1.5 mm deep. The asymmetry of the position of the hind limbs was apparent in about $20 \mathrm{sec}$ after the lesion and indicated the success of the lesion. All six animals in each litter were operated, three of them being controls injected later with the solvents of drugs and three being experimental animals injected with

*This paper is sponsored by James Dyal, who takes full editorial responsibility for it. This work was supported by a grant from the Atkinson Charitable Foundation in Toronto. The author is indebted to Ruth Atkinson-Hindmarsh, President of author is indebted to Ruth Atkinson-Hindmarsh, President of
the Foundation for support. Tricyanoaminopropene (U-9189) was obtained from the Upjohn Company of Canada through the courtesy of E. L. Masson. Pemoline magnesium was obtained from Abbott Laboratories, Scientific Division, North Chicago, Ill. We are indebted to P. W. Dodge and A. O. Geiszler for the sample. We are also grateful to M. G. Stout, of the Nucleic Acid Research Institute, Irvine, Calif., for the sample of ribaminol. The author wishes to express his thanks to $M$. Reinis for her careful and reliable technical help. substances affecting proteosynthesis. A total of 18 litters was tested.

The substances tested were injected every other day intraperitoneally, starting from the third day of postnatal life. The last dose was injected on the 13th day of postnatal life. Three substances were administered: 1,1 , 3-tricyano-2-amino-1-propene (TCAP) a dimer of malononitril, dissolved in physiological saline, $20 \mathrm{mg} / \mathrm{kg}$; pemoline magnesium in $5 \%$ acacia gum, $30 \mathrm{mg} / \mathrm{kg}$; and ribaminol, in physiological saline, $50 \mathrm{mg} / \mathrm{kg}$. Recovery, i.e., the return of symmetry of position of the hind limbs when the animals were held on their backs, was evaluated by two independent Os.

\section{RESULTS AND DISCUSSION}

The results are summarized in Table 1 . The values of 18 animals in each group, expressed as percentages of the total number, show that the substances tested did not substantially change the rate of the recovery. None of the drugs tested was able to enhance the recovery of the damaged brain function.

In our previous papers (Reinis, 1960, 1973), we showed that spontaneous nervous reorganization may be accompanied by long-lasting changes of brain metabolism as tissue respiration, tissue temperature, and also turnover of DNA. The existence of these changes, which implies the presence of a permanent adaptation of the cell metabolism, prompted us to perform this experiment. This experiment is in the nature of a pilot study, because there were too many unknown factors: Do these drugs enter the central nervous system? Do they really alter the metabolism of nucleic acids and proteins? Are they really able to promote functions of the brain? There is no definitive answer to all three questions in the available literature. However, it was tempting to study the effect of these drugs on one of the phenomena associated with brain plasticity, that is, recovery from brain damage. There is at present no explanation of the mechanisms of recovery of the brain from damage. The general term, "plasticity," does not explain the mechanisms of formations of new connections or the molecular mechanisms controlling them. This study is a part of our plan for studying the molecular and cellular phenomena underlying brain plasticity. It is based on the idea that several

Table 1

Effect of Ribaminol, Magnesium Pemoline, and TCAP on the Recovery of Mice from the Cerebellar Damage*

\begin{tabular}{|c|c|c|c|c|c|c|}
\hline \multirow{2}{*}{ 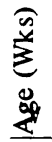 } & \multicolumn{2}{|c|}{ Ribaminol } & \multicolumn{2}{|c|}{ Magnesium Pemoline } & \multicolumn{2}{|c|}{ TCAP } \\
\hline & $\begin{array}{l}\text { Con- } \\
\text { trols }\end{array}$ & Injected & $\begin{array}{l}\text { Con- } \\
\text { trols }\end{array}$ & Injected & $\begin{array}{l}\text { Con- } \\
\text { trols }\end{array}$ & Injected \\
\hline 1 & 5.6 & 5.6 & 5.6 & 11.1 & 0.0 & 5.6 \\
\hline 3 & 11.1 & 22.2 & 11.1 & 16.6 & 11.1 & 11.1 \\
\hline 6 & 20.0 & 5.6 & 11.1 & 22.2 & 11.1 & 20.0 \\
\hline 8 & 27.6 & 27.8 & 27.8 & 33.3 & 27.8 & 27.8 \\
\hline
\end{tabular}

*Values expressed in percentage of animals that completely recovered. 
phenomena, e.g., recovery of the damaged brain, development of epilepsy after brain lesion, changes caused by experience, metabolic adaptation of the brain to change of nutrition, metabolic correlates of drug tolerance, and dependence, may have several common features and may be explained by basically similar or identical cellular and molecular phenomena.

\section{REFERENCES}

Cameron, D. E. The use of nucleic acid in aged patients with memory impairment. American Journal of Psychiatry, 1958 $114,943-957$.

Chamberlain, T. J.. Rothschild, G. H., \& Gerard, R. W. Drugs affecting RNA and learning. Proceedings of the National Academy of Sciences, 1963, 49, 918-924.

Glasky, A. J., Simon, L. N., \& Tallman, P. Pibaminol: Enhancement of conditioned avoidance learning. Life Sciences, 1968, 7, 657-666.
Mendelsor, J., Mendelson, J. G., Fox, B., \& Grenell, R. G. Stability and absorption spectrum of Malononitrile. Science, $1954,120,266-269$.

Plotnik off, N. Magnesium pemoline: Enhancement of learning and memory of a conditioned avoidance response. Science, $1966,157,703-704$

Reinis, $S$. Metabolische Veranderungen des zentralen Nervensystems nach Unterbrechung der zum Neopallium führenden Nervenfasern. Pflügers Archiv, 1960, 271, 316-322.

Reinis, S. Changes in the relative vascularity of various parts of the central nervous system. Plzensky Lekarsky Sbornik, $1966,26,31-34$.

Reinis, S., \& Suva, J. Changes of the activity of brain phosphatases and transaminases after the early damage to the central nervous system. Plzensky Lekarsky Sbornik, 1966, 26. 31-34.

(Received for publication August 28, 1973.) 